\title{
ISOLASI BAKTERI LAUT DARI PERAIRAN MALALAYANG SULAWESI UTARA
}

\author{
(Isolation of Marine Bacteria From Malalayang Waters, North Sulawesi)
}

\section{Bella Wondal ${ }^{1 *}$, Elvy Like Ginting ${ }^{1}$, Veibe Warouw ${ }^{1}$, Stenly Wullur ${ }^{1}$, Sandra Olivia Tilaar $^{1}$, Ferdinand Frans $^{1}$ Tilaar $^{2}$}

1. Program Studi Ilmu Kelautan, Fakultas Perikanan dan Ilmu Kelautan, Universitas Sam Ratulangi.

2. Program Studi Manajemen Sumberdaya Perikanan, FPIK Unsrat

*e-mail : bellajohanawondal26@gmail.com

\section{ABSTRACT}

Marine bacteria have a lot of potential in exploring the enzyme that can be developed, such as a producer of proteorhodopsin, act as hydrocarbon chlorlastic and can degrade oil. This study aims to obtain isolates and can characterize the bacterial morphology. Malalayang Waters is one of the marine bacterial habitats that has potential area to be studied. This study aims to isolate marine bacteria from Malalayang Waters. These marine bacteria first were diluted into sea water before they were grown on Nutrient Agar (NA). Based on the results of this study it was found that marine bacterial isolated were separated based on their morphological characteristics. The dominant morphological characteristics were yellow whites which dominant shape were irregular.

Keywords: bacterial, dilution, isolation.

\section{RINGKASAN}

Bakteri laut memiliki banyak potensi yang dapat dikembangkan. Seperti penghasil proteorhodopsin, berperan sebagai hidrokarbonoklastik dan dapat mendegradasi minyak. Perairan Malalayang merupakan salah satu habitat bakteri laut yang belum diteliti. Penelitian ini bertujuan untuk mengisolasi bakteri laut dari Perairan Malalayang. Bakteri laut ditumbuhkan pada media agar + air laut, selain itu bakteri juga dilakukan pengenceran terhadap air laut sebelum bakteri ditumbuhkan pada media Nutrient Agar (NA). Berdasarkan hasil penelitian ini isolat bakteri laut ditemukan, bakteri tersebut dipisahkan berdasarkan karakteristik morfologinya. Karakteristik morfologi yang dimiliki dominan berwarna putih kuning dan memiliki bentuk yang dominan tidak teratur. Hal ini dapat memperlihatkan perbedaan bakteri laut dari Perairan Malalayang yang tumbuh.

Kata kunci: bakteri, pengenceran, isolasi.

\section{PENDAHULUAN}

Perairan Malalayang terletak di
ujung selatan Kota Manado Provinsi
Sulawesi Utara yang memiliki potensi untuk
dikembangkan Salah satu yang dapat
dikembangkan dari perairan ini adalah
bakteri yang mana bakteri dapat ditemukan
pada lokasi dan obyek yang luas diperairan
laut, salah satunya adalah pada substrat
permukaan dasar perairan (Wahyuni,2013).
Bakteri di laut mempunyai peranan yang

sangat penting di dalam menjaga kesinambungan kehidupan laut karena bakteri mempunyai kemampuan untuk mendegradasi senyawa organik menjadi senyawa anorganik.

Bakteri di alam umumnya tumbuh dalam populasi yang terdiri dari berbagai spesies. Oleh karena itu, untuk mendapatkan biakan murni, sumber bakteri harus diperlakukan dengan pengenceran, agar di dapat hanya 100-200 bakteri yang ditransfer ke medium, sehingga dapat 
tumbuh menjadi koloni yang berasal dari bakteri tunggal (Pelczar \& Chan, 1986).

Proses pemisahan / pemurnian dari bakteri lain perlu dilakukan karena semua pekerjaan mikrobiologis memerlukan suatu populasi yang hanya terdiri dari satu macam mikroorganisme saja. Teknik tersebut dikenal dengan isolasi bakteri. Terdapat berbagai cara mengisolasi bakteri, yaitu isolasi pada agar cawan, isolasi pada medium cair, dan isolasi sel tunggal (Hardiaty $d k k, 2011$ ).

Oleh sebab itu, lewat penelitian ini bakteri akan diisolasi dari Perairan Malalayang.

\section{METODE PENELITIAN}

\section{Pengambilan Sampel}

Sampel air laut diambil di Perairan Malalayang, Sulawesi Utara (Gambar 1). Pengambilan sampel air laut dilakukan dengan mengambil air laut saat air laut surut dan dimasukkan kedalam botol. Setelah itu sampel tersebut dibawa ke Laboratorium Biologi Molekuler dan Farmasetika Laut Fakultas Perikanan dan Ilmu Kelautan untuk diisolasi bakteri yang hidup didalamnya.

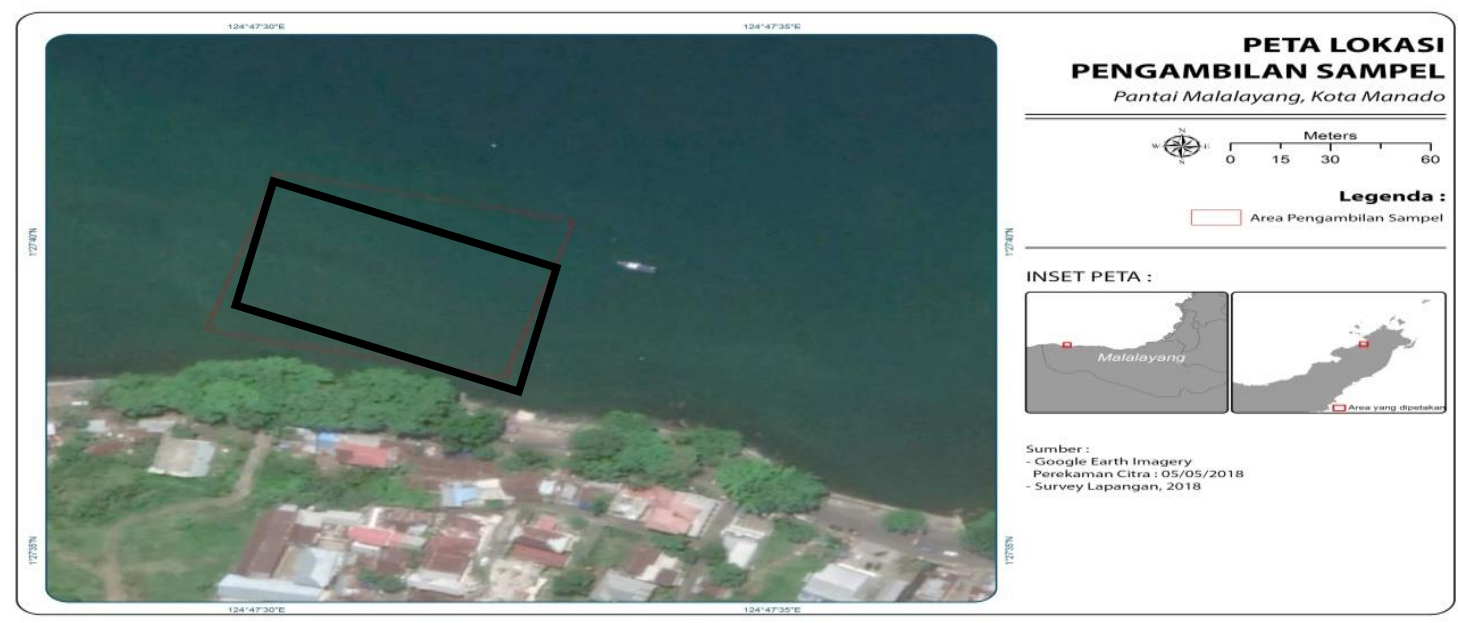

Gambar 1. Peta Pengambilan Sampel

\section{Media Pertumbuhan Bakteri}

Sebelum dilakukan kultur bakteri, disiapkan terlebih dahulu media kultur bakteri. Media kultur bakteri yaitu media Nutrient Agar (NA)

Media nutrient agar dibuat dengan tujuan sebagai media kultur isolat bakteri. Sebelum membuat media nutrient agar, dilakukan sterilisasi cawan petri di dalam autoclave selama \pm 1 jam dengan suhu $121^{\circ} \mathrm{C}$. Setelah itu, bahan media agar dibuat dengan mencampurkan 1 gram nutrient broth (1\%), dan 2 gram agar (2\%) ke dalam $50 \mathrm{ml}$ air laut steril dan $50 \mathrm{ml}$ aquades pada Erlenmeyer yang berkapasitas $250 \mathrm{ml}$ dan diaduk menggunakan magnetic steerer. Setelah bahan teraduk secara sempurna, erlenmeyer ditutup menggunakan kapas dan alumunium foil dan disterilkan.

\section{Pengenceran Sampel}

Pengenceran sampel ini bertujuan untuk memperoleh isolat murni bakteri. Setiap koloni bakteri yang tumbuh dipisahkan berdasarkan warna, ukuran dan 
bentuk koloni kemudian diisolasi dengan menumbuhkannya pada media yang sama menggunakan autoclave dengan suhu $121^{\circ} \mathrm{C}$ selama \pm 1 jam .

Adapun proses pengenceran yang di lakukan dengan cara : $1 \mathrm{ml}$ sampel air laut diteteskan kedalam $9 \mathrm{ml}$ air laut steril pada tabung reaksi kemudian dilanjutkan ke tabung kedua hingga tabung ketiga kemudian beri label setiap tabung untuk menunjukkan pengenceran pertama hingga keempat. Ketiga tabung reaksi itu masingmasing di homogen (campur) mengunakan mikro pipet.

Media yang sudah steril kemudian dituang dan dibagi secara aseptik ke dalam petry disk steril. Selanjutnya, media agar didiamkan hingga mengeras dan ditutup menggunakan Cling Wrap agar tidak terkontaminasi. Setelah mengeras dan dingin, dibungkus mengggunakan plastik pembungkus dan diletakkan di dalam inkubator selama $2 \times 24$ jam untuk memastikan media dalam keadaan steril dan tidak kontaminasi. Media agar digunakan sebagai media tumbuh dan isolasi bakteri.

\section{Isolasi Bakteri}

Sampel hasil pengenceran kemudian disebarkan dalam media NA dengan menggunakan metode penyebaran (spread) dengan cara mengambil $100 \mu \mathrm{l}$ sampel hasil pengenceran, dan masing masing dituang di atas media NA dan disebarkan menggunakan L-glass. Diinkubasi pada suhu $37^{\circ} \mathrm{C}$ selama $24-48$ jam. Diamati koloni bakteri yang tumbuh. Setiap koloni bebas bakteri yang tumbuh dikarakterisasi berdasarkan karakteristik morfologi dandiisolasi. Adapun karakteristik morfologi yang diamati meliputi warna, elevasi, ukuran dan tepian koloni bakteri.

\section{Karakterisasi Morfologi Bakteri}

Setelah diperoleh koloni bebas bakteri hasil pengennceran, tahap selanjutnya dilakukan karakterisasi morfologi bakteri yang bertujuan untuk melihat ciri-ciri dari bakteri secara fisik.
Hasil karakterisasi morfologi bakteri digambarkan dalam bentuk tabel berdasarkan ukuran, warna, tepian, elevasi, dan bentuk koloni. Morfologi bakteri tersebut ditentukan berdasarkan bentuk koloni bakteri dari Leboffe (2012).

Koloni bakteri yang didapatkan, diamati dan dibedakan berdasarkan perbedaan ukuran, warna, bentuk tepi, pertumbuhan koloni, dan bentuk koloni secara keseluruhan menggunakan patokan karakteristik bakteri dari Leboffe (2012).

Bakteri yang tumbuh pada media agar kemudian di tumbuhkan lagi untuk memperbanyak stok bakteri pada media agar miring. Pembuatan media agar miring dilakukan dengan membuat media agar pada tabung reaksi. Media agar miring dibuat dengan dengan mencampurkan 0,5 gram nutrient broth (1\%), dan 1 gram agar (2\%) ke dalam $2 \mathrm{ml}$ air laut steril dan $25 \mathrm{ml}$ aquades pada Erlenmeyer yang berkapasitas $100 \mathrm{ml}$ dan diaduk menggunakan magnetic steerer. Setelah bahan teraduk secara sempurna, erlenmeyer ditutup menggunakan kapas dan alumunium foil dan disterilkan.

Media agar yang steril kemudian dibagi secara aseptic kedalam tabung reaksi. Selanjutnya, media agar didiamkan hingga mengeras dan ditutup menggunakan Cling Wrap agar tidak terkontaminasi. Setelah mengeras dan dingin, dibungkus mengggunakan plastik pembungkus dan diletakkan di dalam inkubator selama $2 \times 24$ jam untuk memastikan media dalam keadaan steril dan tidak kontaminasi. Bakteri yang ada kemudian diinokulasikan menggunakan jarum ose ke dalam media miring.

\section{HASIL DAN PEMBAHASAN}

Berdasarkan hasil penelitian, 6 isolat bakteri berhasil diisolasi dari Perairan Malalayang. Enam bakteri tersebut diperoleh setelah dilakukan pengenceran $10^{-1}$ sampai $10^{-3}$ dan diperoleh koloni bebas yang terlihat pada Gambar 2. Pada pengenceran $10^{-1}$ koloni bakteri yang tumbuh sangat padat selanjutnya pada 
pengenceran $10^{-2}$ kepadatan koloni bakteri berkurang dan pada pengenceran $10^{-3}$ diperoleh koloni bebas bakteri.

Koloni bakteri yang ada kemudian ditumbuhkan pada media Nutrient Agar (NA) dan air laut. Pertumbuhan bakteri pada media NA disebabkan karena media tersebut mengandung nutrisi yang dapat mendukung pertumbuhan bakteri. Menurut Pelczar dan Chan, (2008), semua organisme termasuk bakteri membutuhkan nutrisi untuk memenuhi kehidupan yang diperlukan dalam pertumbuhan organisme tersebut. Air laut digunakan karena sampel merupakan air laut.

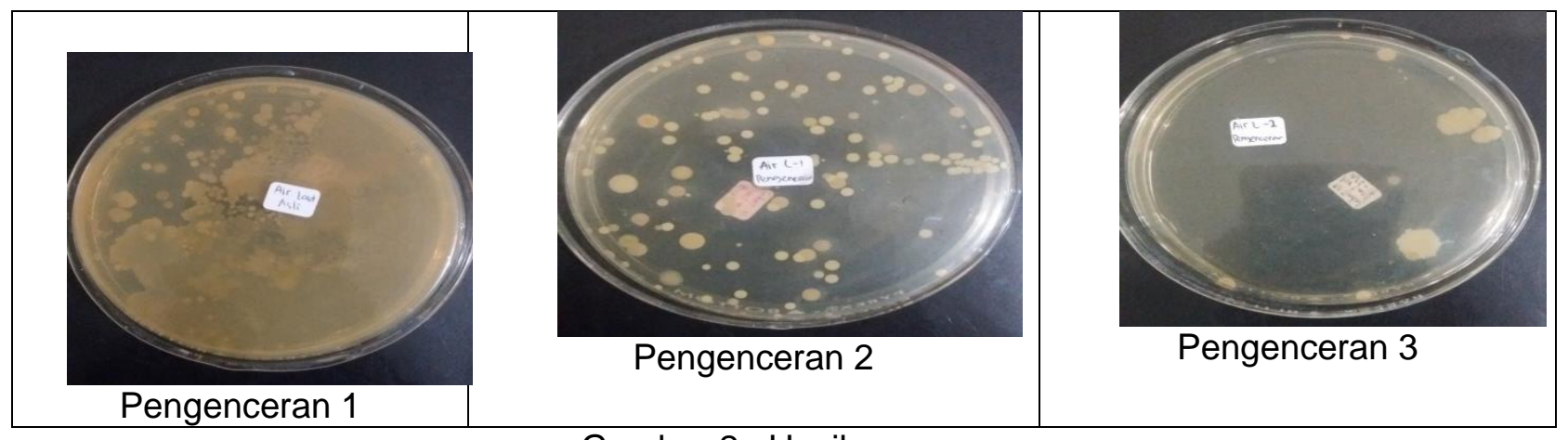

Gambar 2. Hasil pengenceran

Setiap koloni bakteri yang tumbuh dipisahkan berdasarkan warna, ukuran dan bentuk koloni, serta dimurnikan dengan menumbuhkannya pada media yang sama yang dapat dilihat pada Gambar 3. Karakteristik koloni bakteri yang diamati meliputi bentuk,warna, elevasi, dan tepian (Dwijoseputro, 1989). Karakteristik morfologi bakteri diamati berdasarkan Cappucino dan Sherman, (1998). Hasil pengamatan morfologi setiap koloni bakteri air laut disajikan pada Tabel 1.

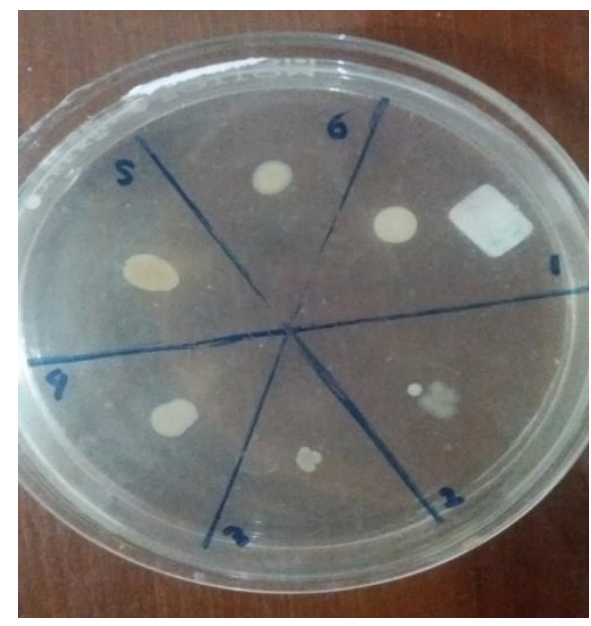

Gambar 3. Koloni Bakteri Laut 
Tabel 1. Karakteristik Morfologi Isolat Bakteri Laut

\begin{tabular}{|l|l|l|l|l|}
\hline Nama & Warna & Tepian & Bentuk & Elevasi \\
\hline MWM 1 & Putih bening & Entire & Round & Convex \\
\hline MWM 2 & Putih susu & Lobate & Irregular & Convex \\
\hline MWM 3 & Putih kuning & Lobate & Irregular & Plateau \\
\hline MWM4 & Putih kuning & Eros & Irregular & Flat \\
\hline MWM5 & Putih kuning & Lobate & Irregular & Flat \\
\hline MWM6 & Putih kuning & Entire & Round & Flat \\
\hline
\end{tabular}

Terlihat pada Tabel 1, bahwa setiap isolat memiliki karakteristik morfologi yang berbeda baik bentuk koloni, tepian, warna maupun elevasi. Kelima isolat bakteri laut Perairan Malalayang didominasi warna putih kuning dan memiliki bentuk koloni bakteri dominan Irregular atau bulat. Hal ini disebabkan karena kepadatan dan kerapatan sel bakteri serta ketersediaan nutrisi dalam media pertumbuhan (Wiley $d k k, 2008)$

Bakteri simbion dua jenis alga merah yaitu Gracilaria sp.dan Portieria sp dari Perairan Tongkeina Sulawesi Utara juga telah berhasil diisolasi dan diperoleh karakterisik yang berbeda dan lima dari kesepuluh isolat bakteri memililiki bentuk morfologi irregular atau tidak teratur (Ginting $d k k$, 2019). Dari periaran Tongkaina Sulawesi Utara juga telah berhasil diisolasi bakteri simbion spons dan diperoleh sepuluh isolat bakteri yang bersimbiosis dengan dua jenis spons yakni
Facaplisynopsis sp. dan Agelas sp. dengan karaktersitik morfologi yang bervariasi. Kesepuluh isolat bakteri tersebut memiliki karakteristik yang umumnya berwarna putih dan kuning dengan bentuk circular (Wantania $d k k, 2016)$ dan bakteri tersebut telah berhasil diamplifikasi menggunakan primer 8F dan 1492R (Rangian $d k k, 2018$ ).

Napitupulu, dkk (2019) telah mengisolasi bakteri sebagai media kultur rotifer dan diperoleh dua bakteri yang memiliki karakteristik yang berbeda akan tetapi pada saat dianalisis molekuler menunjukan bahwa jenis-jenis bakteri ini tergolong dalam genus Bacillus sp. Subaryono dkk., (2015) telah mengidentifikasi empat bakteri yang memiliki indeks alginolitik dengan morfologi yang berbeda selanjutnya diidentifikasi molekuler dan menunjukkan kemiripan dengan genus Bacilius. 


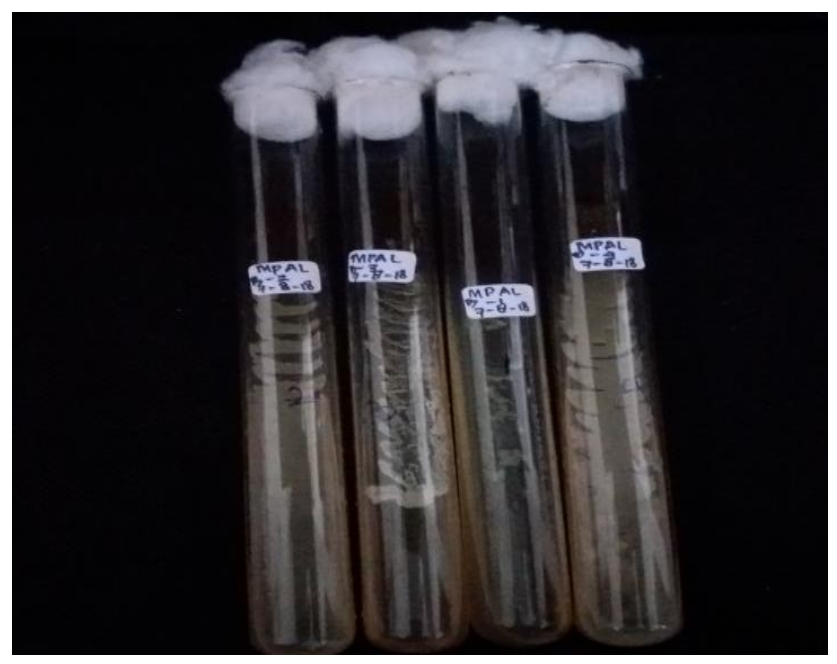

Gambar 3. Isolat Bakteri pada Media Miring

Bakteri laut hasil penelitian ini, lebih lanjut dapat diteliti potensinya Bakteri laut dilaporkan memiliki banyak manfaat seperti penghasil proteorhodopsin dari untuk aplikasi sel tenaga surya (Tapilatu, 2012), berperan sebagai hidrokarbonoklastik $\mathrm{PAH}$ fenotiazin (Yetti $d k k, 2016)$ dan juga bakteri laut dibuktikan dapat mendegradasi minyak (Shaumi dkk, 2018)

Isolat bakteri yang telah dipisahkan kemudian ditumbuhkan pada media Nutrient Agar miring untuk dijadikan stok Penampakan bakteri yang tumbuh pada media agar miring dapat dilihat pada Gambar 5.

\section{Kesimpulan}

Berdasarkan hasil penelitian, enam isolat bakteri laut dari Perairan Malalayang berhasil diisolasi dan bakteri tersebut telah dikarakterisasi morfologinya berdasarkan bentuk, elevasi, tepian dan warna.

\section{Daftar Pustaka}

Cappucino, J.G., dan Sherman, N. 1998. Microbiology: A Laboratory Manual. 5th Edition. California: Benjamin/Cummings Science Publishing. p:94
Dwijoseputo. 2005. Dasar- dasar Mikrobiologi. PT Penerbit Djambatan. Jakarta.

Ginting, E. L., Rangian, L., Wantania, L. L., dan Wullur, S. 2019. Isolasi Bakteri Simbion Alga Merah dari Perairan Tongkeina, Sulawesi Utara. Jurnal Ilmiah Platax. 7(2): 394-400.

Hardiaty, S., Amalia, S., Suparmin, R., Ernawati, T., Febrianti, V., dan Syam,Y,. 2011. Inokulasi Bakteri. Laporan Hasil Penelitian Jurusan Farmasi. Makasar: Politeknik Kesehatan Kemenkes.

Leboffe, M. J dan B. E. Pierce. 2012. Brief Microbiology. Laboratory Theory \& Application 2nd Edition. Englewood: Morton Publishing.Madigan, M., Stahl., dan Clark. 2012. Biology of Microorganisms. Pearson Education,Inc. San Francisco. Hal 144.

Napitupulu, H. G., Rumengan, I. F., Wullur, S., Ginting, E. L., Rimper, J. R. T. S. L., dan Toloh, B. H. 2019. Bacillus sp. sebagai Agensia Pengurai dalam Pemeliharaan Brachionus rotundiformis yang Menggunakan Ikan Mentah sebagai Sumber Nutrisi. Jurnal IImiah Platax. 7(1) :158-169. 
Pelczar, M. J., dan Chan, E. C. S. 1986. Dasar-Dasar Mikrobiologi,. Isolasi dan Identifikasi Mikroba. Jakarta : widiya medika. Hal 190-191.

Pelczar, M. J., dan Chan, E.C. S. 2008. Dasar-Dasar Mikrobiologi.Universitas Indonesia Press. Jakarta.

Rangian, L., Ginting, E. L., Wullur, S., Kaligis, E., Tilaar, S., dan Tumbol, R. 2017. Amplifikasi Isolat Bakteri SF1 Simbion Spons Facaplysynopsis sp. Dari Perairan Tongkeina, Sulawesi Utara. Jurnal Platax. 6(2): 77-82.

Shaumi, N, Nursyiwani., dan Feliatra. 2018. Kemampuan Degradasi dan Identifikasi Bakteri Pendegradasi Minyak dengan Sekuens 16S rRNA. Jurnal Universitas Riau.

Subaryono., Peranginangin, R., Suhartono, M. T., dan Zakaria. F. R. 2015. Isolasi dan Identifikasi Bakteri Penghasil Alginat Lyasae dari Rumput Laut Sargassum crassifolium. JPB Kelautan dan Perikanan 10(1): 1-9.

Tapilatu, Y. 2012. Eksplorasi Bakteri Laut Penghasil Proteorhodopsin dari Perairan Maluku Untuk Aplikasi Sel
Tenaga Surya.Prosiding Isinas. 084: 39-43.

Wahyuni, E. A. (2013) 'Studi Pendahuluan Kandungan Mikroba Dalam Sedimen Permukaan Dasar Di Perairan Selat Madura, Kabupaten Bangkalan', in, pp. 658-661.

Waluyo, L. 2004. Mikrobiologi Umum. UMM PRESS,Malang.

Wantania, L. L., Ginting, E. L., dan Wullur, S. 2016. Isolasi Bakteri SImbion dengan Spons dari Perairan Tongkeina, Sulawesi Utara. Jurnal LPPM Bidang Sains dan Teknologi. 3(1):57-65.

Willey, J. M., Sherwood, L. M. dan Woolverton., 2008. Prescott, Harley, and Klein's Microbiology Seventh Edition. Newyork: McGraw-Hill.

Yetti, E. Tonthowi,A., dan Yopi. 2016. Penapisan dan Optimasi Pertumbuhan Bakteri Laut yang Berpotensi sebagai Hidrokarbonoklastik $P A H$ Fenotiazin. JPB Kelautan dan Perikanan 11(2):127-138. 